\title{
Retrospective analysis of burn windows for fire and fuels management: an example from the Lake Tahoe Basin, California, USA
}

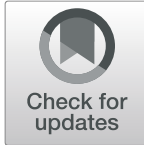

Randy Striplin ${ }^{1,2^{*}}$, Stephanie A. McAfee ${ }^{2,3}$, Hugh D. Safford ${ }^{1,4}$ and Michael J. Papa ${ }^{5}$

\begin{abstract}
Background: In fire-adapted ecosystems of the western USA, prescribed fire is an essential restoration and fuel reduction tool. There is general concern that, as the fire season lengthens, the window for conducting prescribed burns will contract unless management changes are made. This could occur because a number of conditions must be met before prescribed fire can be used in the field, and those are most common during the spring and autumn when the need for fire suppression response has been historically less. To assess patterns of potential prescribed burning feasibility, this study evaluated three conditions: (1) permission to burn as granted by air quality regulators; (2) weather within burn plan prescription; and (3) availability of operational and contingency resources. Our 21-year analysis (1999 to 2019) combines three independent datasets for a daily comparison of when prescribed fires could have been implemented (henceforth, burn windows) in the Lake Tahoe Basin (LTB) and analyzes seasonality, interannual variability, and trends.

Results: Burn windows were most frequent during spring, followed by autumn, with the fewest burn windows during the summer and winter. Burn windows lasting multiple days occurred infrequently. Two- to three-day burn windows did not often occur more than twice per month over the study period, and longer burn windows were very rare. Interannual variation was considerable. Finally, an abrupt increase in burn windows was detected in 2008. This was determined to be related to a methodological change by air quality regulators and not to any changes in climate or resource availability.

Conclusions: While this case study focuses on the LTB, the analysis was performed with readily available data and could be applied easily to other land management units, demonstrating a valuable method for planning and prioritizing fire and fuels management activities. This type of tool can also identify areas for research. For example, if there were unused burn windows during the winter and early spring —or they were projected to increaseresearch into the ecological impacts of winter and spring burning may allow managers to more confidently adapt to changing climate. Moreover, this analysis demonstrated that modest and reasonable regulatory changes can increase opportunities for prescribed burning.
\end{abstract}

Keywords: burn window, climate change, mixed conifer forest, prescribed fire, western USA

\footnotetext{
* Correspondence: randy.striplin@usda.gov

'USDA Forest Service, Pacific Southwest Region, 1323 Club Drive, Vallejo,

California 94592, USA

${ }^{2}$ Department of Geography, University of Nevada, Reno, 1664 North Virginia

Street, Reno, Nevada 89557, USA

Full list of author information is available at the end of the article
}

\section{Springer Open}

(c) The Author(s). 2020 Open Access This article is licensed under a Creative Commons Attribution 4.0 International License, which permits use, sharing, adaptation, distribution and reproduction in any medium or format, as long as you give appropriate credit to the original author(s) and the source, provide a link to the Creative Commons licence, and indicate if changes were made. The images or other third party material in this article are included in the article's Creative Commons licence, unless indicated otherwise in a credit line to the material. If material is not included in the article's Creative Commons licence and your intended use is not permitted by statutory regulation or exceeds the permitted use, you will need to obtain permission directly from the copyright holder. To view a copy of this licence, visit http://creativecommons.org/licenses/by/4.0/. 


\section{Resumen}

Antecedentes: En ecosistemas adaptados al fuego en el oeste de los EEUU, las quemas prescriptas son una herramienta esencial para la restauración y reducción de combustibles. Existe un consenso general sobre que, si la estación de fuegos se prolonga, la ventana de prescripción para conducir quemas prescriptas se contrae a menos que se hagan cambios en el manejo. Esto puede ocurrir dado que cierto número de condiciones deben ser cumplidas antes de que las quemas puedan ser aplicadas en el campo, y éstas se dan más comúnmente en primavera y otoño, cuando las necesidades de supresión son históricamente menores. Para determinar el patrón de posibilidades de aplicación de quemas, este estudio evaluó tres condiciones: (1) el permiso de quema otorgado por reguladores de la calidad del aire; (2) el tiempo meteorológico dentro del plan de prescripción; y (3) la

disponibilidad de recursos de contingencia y operacionales. Nuestros análisis de 21 años (1999 a 2019) combinaron tres conjuntos de datos independientes para una comparación diaria sobre cuando las quemas deberían haber sido implementadas (ventana de quemas de aquí en más) en la cuenca del lago Tahoe (LTB) y analizó la estacionalidad, la variabilidad interanual, y las tendencias.

Resultados: Las ventanas de quema fueron más frecuentes durante la primavera seguidas del otoño, con la menor cantidad de ventanas de quemas durante el verano y el invierno. Las ventanas de quemas que duraban varios días ocurrían de manera infrecuente. Las ventanas que duraban dos a tres días no ocurrían más que dos veces por mes en todo el período de estudio, y ventanas que iban más allá de este período fueron realmente raras. La variación interanual también fue considerable. Finalmente, un abrupto incremento de ventanas de quemas fue detectado en 2008. Esto fue determinado que estuvo relacionado a un cambio en la metodología usada por los reguladores de cambios en la calidad del aire y no por cambios meteorológicos o en la disponibilidad de recursos.

Conclusiones: Aunque este estudio de caso se enfoca en LTB, el análisis fue realizado con datos rápidamente disponibles que pueden fácilmente ser aplicados a otras unidades de manejo, demostrando ser un método valioso para planificar y priorizar quemas y actividades de manejo de combustibles. Este tipo de herramienta puede identificar también áreas para la investigación. Por ejemplo, si hubiese ventanas de quemas no usadas durante el invierno y la primavera temprana - o si fuese proyectado su incremento-la investigación sobre los impactos ecológicos de las quemas de invierno o primavera podrían permitir a los gestores de recursos adaptarse con más confianza al cambio climático. Este análisis demostró, además, que cambios regulatorios modestos y razonables pueden incrementar las oportunidades para realizar quemas prescriptas.

\section{Abbreviations}

CARB: California Air Resource Board

COOP: Cooperative Observer Program

FFP5: Fire Family Plus v. 5

FR: $\quad$ Fire regime

LTB: Lake Tahoe Basin

PL: $\quad$ Preparedness level

NOPS: Northern California Geographic Area

NWS: National Weather Service

ONCC: Northern California Geographic Area Coordination Center

RAWS: Remote automated weather station

USDA: United States Department of Agriculture

WRCC: Western Regional Climate Center

WUI: Wildland-urban interface

WY: Water year

\section{Background}

Human management has greatly altered forests in the western USA since Euro-Americans arrived in the mid 1800s. In forests that historically experienced frequent, mostly low-severity fire (i.e., Fire Regime 1 forests [FR1],
Hardy et al. 2001), logging and fire exclusion have caused major changes, including loss of the large tree component, increases in stand density and surface and ladder fuels, as well as compositional shifts toward shade-tolerant and fire-intolerant tree species (Safford and Stevens 2017). In the last two to three decades, warming and drying have interacted with these forest changes to drive an increase in the occurrence of wildfires that are burning at unprecedented scales and severities, killing large areas of canopy trees, and increasingly threatening human life and property (Miller et al. 2009; Abatzoglou and Williams 2016; Safford and Stevens 2017; Holden et al. 2018; van Wagtendonk et al. 2018).

Reducing risks to communities and natural resources is a top priority for land managers. As a result, the United States Department of Agriculture (USDA) Forest Service continues to invest heavily in community risk reduction and has recently emphasized increasing the pace and scale of ecological restoration (USDA Forest Service Pacific Southwest Region 2011; USDA Forest Service 2012; Agee et al. 2016). In FR1 forests, frequent thinning and other types of fuel reduction followed by prescribed 
fire are usually the most effective fuels management and forest restoration tools (Agee and Skinner 2005; Stephens and Moghaddas 2005; North et al. 2009; aillant and Stephens 2009; McIver et al. 2013). Some studies have also found that prescribed fire alone reduces surface and ladder fuels and is successful in mitigating the risk of crown fire under extreme weather conditions (Kilgore and Sando 1975; Stephens et al. 2012).

Despite the clear need for management to reduce wildfire risk, a recent analysis found that, in much of the western USA, use of prescribed fire has declined since the late 1990s (Kolden 2019). This reduction has occurred despite an acknowledged "backlog" in forest management (North et al. 2012; Vaillant and Reinhardt 2017). Although Kolden (2019) attributes some of the reticence around prescribed fire use in the western USA to societal concerns, there are clear practical constraints to its use as well (Quinn-Davidson and Varner 2012).

Prescribed fire is effective at reducing wildfire threats, but there are risks associated with it, so the practice is strictly regulated. A variety of conditions need to be met prior to prescribed burning on federal lands (National Wildfire Coordinating Group 2017). Weather conditions (forecasted and observed) must be within prescriptive criteria established in the prescribed fire implementation plan. Prescribed fire implementation plans (burn plans) establish a set of environmental conditions (the prescription) under which the burn has a high likelihood of meeting project objectives (National Wildfire Coordinating Group 2017). Operational resources (personnel and equipment) for burn implementation and the contingency plan must be available, and burn permits must be obtained from the jurisdictional air quality regulators. Weather conditions that meet burn plan prescriptions, sufficient resources, and permissible burn days for air quality must occur together on the day or days of the burn before it can proceed. Fire and resource managers know through experience that the coincidence of these events is limiting and can constrain their ability to meet fuels and restoration objectives. Although studies have evaluated seasonal patterns in the weather conditions suitable for the use of prescribed fire (e.g., Yurkonis et al. 2019), there is currently no quantitative method for assessing the frequency with which all of these limitations on prescribed fire coincide.

Describing burn window occurrences, their trends, and the variables constraining them will increase the likelihood of success in meeting restoration and fuel reduction objectives. Information about past patterns and trends in burn windows is important for projecting a reasonable treatment area, given project objectives. Studies suggest that the majority of natural burning historically occurred during the summer wildfire season, sometimes extending into autumn (Taylor 2004; Beaty and Taylor 2008). However, during the wildfire season, weather is warmer and drier, fire suppression resources are often committed to active wildfires, and stable, calm atmospheric conditions are not as conducive to smoke dispersion, so prescribed burning is often discouraged. With all of the limitations described above and the need to increase prescribed burning, both in-fire-season and out-of-fire-season burning may be necessary. Consequently, information on burn-window likelihood is critical for managers intending to restore a natural fire regime or simply address a backlog in prescribed burning.

Understanding when and where weather and fuel conditions are within prescription, and where in the prescriptive range they fall, informs managers about when and how to burn, as well as when to plan burns with specific intended objectives. For instance, burning at the moister end of the prescription will consume less fuel and produce less severe effects than burning at the drier end of the prescription (Knapp et al. 2005; Knapp and Keeley 2006; Schwilk et al. 2006). Either of those outcomes, or any range in between, may be optimal for achieving desired objectives. Knowledge of seasonal patterns in weather conditions can also inform the types of treatment that are most plausible. For example, if burn windows are likely in the spring when soil and fuel moistures are higher, and less common in the summer or autumn, managers may choose to target areas with heavy fuels in the spring, where lower levels of fuel consumption and patchy burns might be desired. Drier conditions in the autumn might be reserved for burns intended to maximize fuel consumption.

Investigation of historical burn-window occurrences and their drivers can improve planning and budgeting. If burn windows are most frequent in spring and autumn, but the workforce tour of duty is scheduled to ramp up in late spring and wind down in early autumn, sufficient resources to implement prescribed fire projects may not be available. The current Forest Service paradigm is to use fire suppression resources to implement prescribed fire projects. During spring, autumn, and winter, fewer seasonal fire personnel are available to conduct burns even though weather and atmospheric conditions are often optimal for implementing prescribed fire. Understanding when regional fire activity and fire suppression resource limitations inhibit capacity can provide an incentive to develop innovative staffing solutions, such as staggering seasonal crew start and end dates to allow for additional staffing in the spring and autumn, or forming dedicated prescribed fire crews, as California Department of Forestry and Fire Protection recently did (State of California 2020). This information will allow managers to scale and better schedule their workforce for success. Furthermore, knowing when air quality effects 
are most likely can inform community outreach and enhance collaboration and cooperation with air quality regulators. Finally, analysis of historical and projected future burn-window occurrences may provide insight into research needed for long-range planning. For instance, research into the ecological implications of winter and spring burns (e.g., Knapp et al. 2005; Knapp and Keeley 2006) is warranted if multiple-day burn periods are or become more likely during spring or winter, when fires have historically been uncommon.

Here, we assess how interactions between weather conditions, air quality regulations, and resource availability influence prescribed fire burn windows in the Lake Tahoe Basin (LTB), California, USA. Our analysis identifies the daily co-occurrence of all three conditions from 1999 through 2019, identifying burn-window patterns to assist managers in planning and implementing prescribed fires. In terms of fire management, we believe that the LTB serves as a reasonable proxy for other inhabited parts of the forested West with similar fuel and forest conditions, but perhaps somewhat higher anthropogenic ignition densities.

\section{Methods}

\section{Study area}

The LTB is at the crest of the Sierra Nevada (approximately $39^{\circ} \mathrm{N}, 120^{\circ} \mathrm{W}$ ) and is shared between California and Nevada (Fig. 1). It spans 132283 hectares, including the approximately 50 000-hectare Lake Tahoe, which sits at approximately $1900 \mathrm{~m}$ elevation surrounded by mountain peaks rising to $>3300 \mathrm{~m}$. Dry, mild summers and cold, wet winters are typical. The January mean minimum temperature at the South Lake Tahoe airport is $-8.8{ }^{\circ} \mathrm{C}$, the July mean maximum temperature is $27.1{ }^{\circ} \mathrm{C}$, and average annual precipitation is about $51.8 \mathrm{~cm}$ (Western Regional Climate Center 2017). Interannual variability in precipitation is high and, like in much of the Sierra Nevada, is increasing over time (Safford et al. 2012a). For instance, the National Weather Service Cooperative Observer Program (NWS COOP) weather station in Tahoe City, California (NWS ID: 048758), on the north shore of the lake, recorded about half the 30-year average precipitation in water year (WY) 2015 (1 Oct 2014 to 30 Sep 2015) and twice the 30 -year average precipitation in WY 2017 (TahoeClim 2017).

Vegetation and fire regimes can be stratified by elevation into three broad groups. Near lake level, the lower montane zone $(<2200 \mathrm{~m})$ is dominated by Jeffrey pine (Pinus jeffreyi Grev. \& Balf.), white fir (Abies concolor [Gordon \& Glend.] Lindl. ex Hildebr.), incense-cedar (Calocedrus decurrens [Torr.] Florin), and sugar pine ( $P$. lambertiana Douglas). The upper montane zone (2200 to $2500 \mathrm{~m}$ ) is dominated by red fir (A. magnifica A. Murray bis), lodgepole pine ( $P$. contorta Loudon ssp. murrayana [Grev. \& Balf.] Critchf.), and western white pine (P. monticola Douglas ex D. Don). The subalpine zone occurs at elevations greater than $2500 \mathrm{~m}$ with red fir, western white pine, mountain hemlock (Tsuga mertensiana [Bong.] Carrière), and whitebark pine ( $P$. albicaulis Engelm.). Montane chaparral stands are scattered throughout, especially in the lower montane zone and the transition to the upper montane zone. Dominant shrub genera include manzanita (Arctostaphylos Adans.spp.), Ceanothus L. spp., and currants and gooseberries (Ribes L. spp.). Historic (pre 1850) fire return intervals averaged about 10 years in the FR1 lower montane zone, 40+ years in the upper montane zone (Fire Regime III, Schmidt et al. 2002), and $>200$ years in subalpine forests (Fire Regime IV) (Elliott-Fisk et al. 1997; Manley et al. 2000; Barbour et al. 2002; Taylor 2004; Nagel and Taylor 2005; Beaty and Taylor 2008). Manley et al. (2000) estimated that, during an average year in the pre-settlement period, between 800 and 3200 ha burned, and mean fire size was probably around 200 to 400 ha (Safford and Stevens 2017). In FR1 forests, fire severities were generally low to moderate, and there was relatively little mortality of mature trees (Skinner and Chang 1996; Manley et al. 2000; Taylor 2004), but fires were more severe at higher elevations (Mallek et al. 2013; van Wagtendonk et al. 2018). Fires occurred mostly in the late summer and autumn (Taylor 2004; Beaty and Taylor 2008).

The human footprint is substantial in the LTB. More than $75 \%$ of the land area inside the LTB is designated as wildland-urban interface (WUI; California Department of Forestry and Fire Protection et al. 2014). The proportion of wildland area near and adjacent to communities and infrastructure adds notable complexity to prescribed fire operations. In addition to approximately 50000 permanent residents, Lake Tahoe receives an estimated 7.7 million recreational visitors per year (LTBMU 2015), increasing the need to ensure fire safety and minimize air quality impacts. The LTB is also jurisdictionally complex, with a matrix of local, private, state, and federal lands spanning two states, five counties, one rural district, multiple cities and townships, and numerous fire protection entities.

\section{Burn window analysis}

Burn windows, as defined here, are determined by the simultaneous occurrence of (1) CARB burn days (days designated by California Air Resources Board [CARB] as burn days); (2) days when weather and fuel-moisture conditions fall within burn plan prescription; and (3) sufficient operational and contingency resources (represented by Northern California Geographic Area and national preparedness levels). Preparedness levels (PL) are dictated by regional burning conditions, fire activity, and 


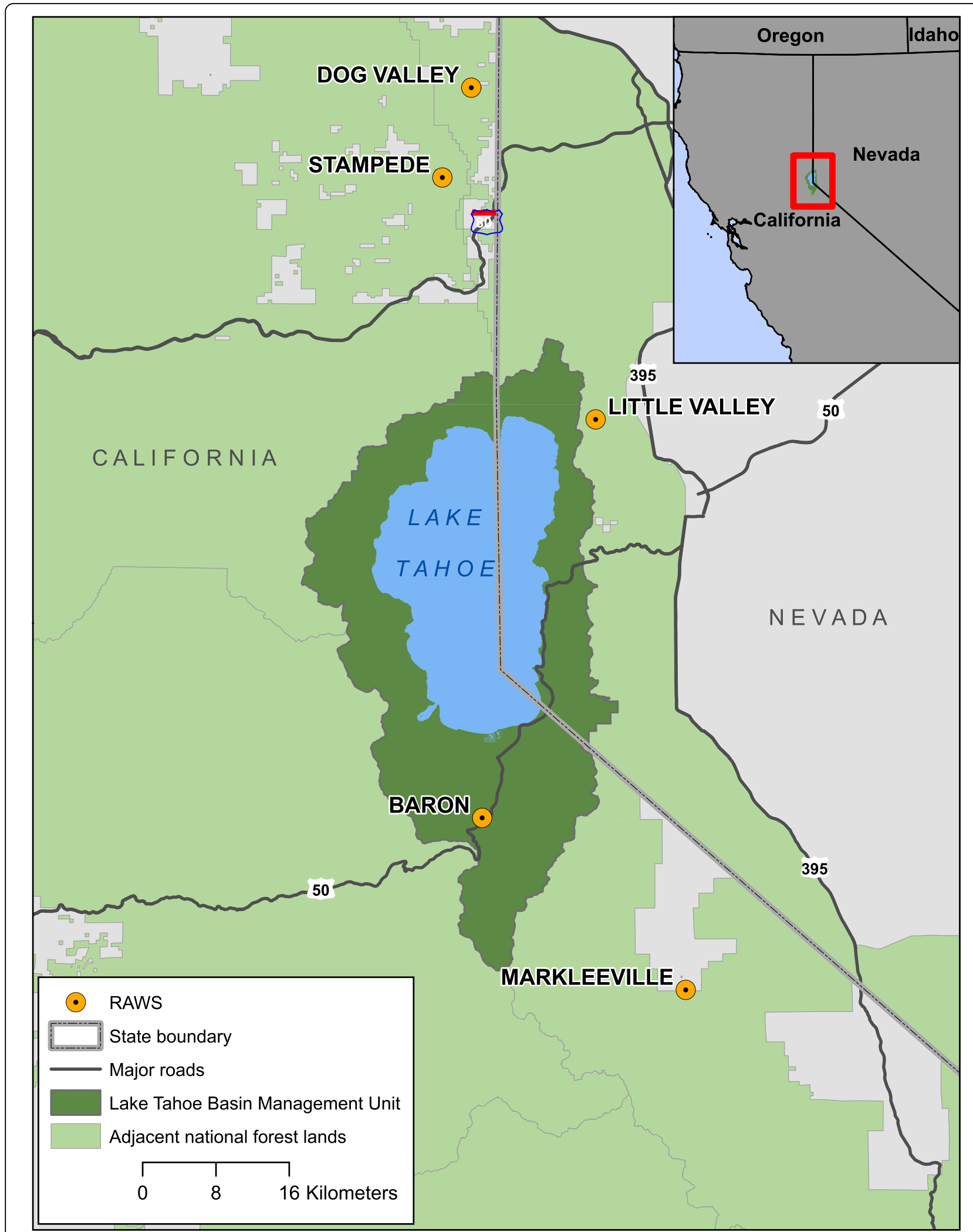

Fig. 1 Map showing the location of remote automated weather station (RAWS) used in the assessment of patterns of potential prescribed burning feasibility in the Lake Tahoe Basin, USA 
resource availability. The availability or unavailability of firefighting resources can often impact resources to implement prescribed fires. Information on operational and contingency resources is not usually incorporated in this type of analysis, but it provides a critical practical constraint.

\section{CARB burn day}

CARB burn days are days on which prescribed burning is permitted by the state board and burning is authorized by each air district consistent with Title 17 of the California Code of Regulations (California 2010). Atmospheric conditions related to smoke dispersal and other sources of air pollution (e.g., wildfires, other prescribed fires, and agricultural burning) factor into burn day determinations. Prescribed fire ignitions are generally not permitted by CARB on days that are not designated as burn days, although there are occasional exceptions, often in consultation with the entity conducting the burn.

We downloaded archived CARB burn day data from http://www.arb.ca.gov/smp/histor/histor.htm for 1 January 1999 to 31 December 2019. California Code of Regulations, Title 17, subchapter 2 (California 2010) designations include burn day, marginal day, and no-burn day. CARB data for the Lake Tahoe Air Basin also include two additional designations: amended and fair. Amended refers to days on which the initial forecast condition was changed from burn to no-burn or from no-burn to burn. Fair and marginal are days on which burning conditions are not ideal, but burning, preferably over smaller areas or of materials that will produce lower emissions, is allowed (D. Mims, California Air Resources Board, Meteorology Section, Sacramento, California, USA, personal communication, 5 September 2019). Over the archive period, there were 4587 burn days, 714 marginal days, 6 amended days, 14 fair days, and 2353 no-burn days. For simplicity of analysis, we assumed that prescribed burns could only occur on days designated as burn days, and not fair or marginal days, on which it is expected that any burning that does occur will be limited. These conditions only applied to the California side of the LTB. The Nevada Division of Environmental Protection regulates smoke management on the Nevada side and may request cessation of burning activities, but they do not proactively designate days as permissive or non-permissive for Forest Service burning activities. The Washoe County Air Quality Management Division requires land managers to acquire permits for prescribed fires that emit greater than $907 \mathrm{~kg}$ of particulate matter of 10 micrometers or less (PM10). Here we use the more stringent and objectively defined California standards to provide a conservative estimate of burn windows for the entire LTB.

\section{Days within prescription}

The burn plan prescription refers to a set of measurable criteria used to determine whether a prescribed fire may be ignited. The prescription includes a set of weather and fuel parameters (ranges of permissible wind speeds, air temperatures, humidity, fuel moistures, etc.) with thresholds based on desired fire behavior and effects. Typical LTB burn plan prescription criteria include (1) minimum relative humidity between 20 and 50\%; (2) 10-hour fuel moisture (10-hour fuels are woody materials between 0.64 and $2.54 \mathrm{~cm}$ diameter) between 7 and 20\%; and (3) maximum wind speeds at $6.1 \mathrm{~m}$ above the ground $<11.2 \mathrm{~m} \mathrm{~s}^{-2}$. On an actual burn, forecasted weather and on-site measurements determine if conditions are within prescription. Continuous data were not available from all past or likely prescribed burn locations, so we estimated days in prescription by comparing weather and fuel moisture data from remote automated weather stations (RAWS) with the prescription criteria outlined above and categorizing days that met all conditions to be in prescription. Specifically, we considered days to be in prescription if the lowest hourly relative humidity measurement in that 24-hour period was between 20 and 50\%, lowest hourly 10hour fuel moisture was between 7 and 20\% (Nelson method calculated by Fire Family Plus v.5; Nelson 2000), and highest hourly maximum $6.1 \mathrm{~m}$ wind speeds were $<11.2 \mathrm{~m} \mathrm{~s}^{-2}$ ). Estimates from RAWS may not be fully representative of sites where burns will be conducted. Estes et al. (2012) reported that RAWS 10-hour fuel moisture estimates at one location were biased low when fuel moistures were over $20 \%$. This could have led us to overestimate the available days in prescription during the spring if findings from their location $(350 \mathrm{~km}$ northwest of the LTB, using an older 10-hour fuel moisture calculation) hold true in the LTB. Based on local experience, however, we believe our methods provided a reasonable estimate of the frequency of days within prescription.

No weather station inside the LTB had continuous hourly data for all the variables needed for this analysis over the full study period, so we combined information from two stations to provide quasi-complete local weather data over the 21-year period. The Baron RAWS $\left(38.85^{\circ} \mathrm{N}, 120.02^{\circ} \mathrm{W}\right.$, elevation $1904 \mathrm{~m}$, NWS ID: 042616) is currently used by the Forest Service for most firerelated purposes in the LTB, but its record extends back only to 21 July 2011 . The Markleeville RAWS $\left(38.69^{\circ} \mathrm{N}\right.$, $119.77^{\circ} \mathrm{W}$, elevation $1677 \mathrm{~m}$, NWS ID: 042802) is $29 \mathrm{~km}$ southeast of the Baron RAWS and outside of the LTB, but it has all necessary data over the full study period. Although the burn window analysis could have been performed using the Markleeville RAWS, managers in the LTB prefer the Baron RAWS. Thus, we used the 
Markleeville RAWS to model Baron RAWS for the period 1 January 1999 through 31 July 2011 using linear regression (see below). In order to assess the similarity of weather observations between the two stations, we conducted a seasonal Pearson correlation analysis (Zar 1999: 377) of temperature and humidity. Table 1 lists Pearson correlation coefficients of seasonal temperature and relative humidity observations for the period of overlap between these RAWS.

Data from the two stations were downloaded from the Western Regional Climate Center (WRCC, http://www. raws.dri.edu/index.html). We used Fire Family Plus v.5 (FFP5; Bradshaw and McCormick 2000) to perform quality control and summarize data. During quality control, we noted suspect wind gust speeds (greater than $45 \mathrm{~m} \mathrm{~s}^{-2}$ ) at Baron RAWS from June through 4 October 2016. As a result, we excluded Baron RAWS wind gust speed data from 1 June 2016 to 4 October 2016, when the wind sensor was replaced. The four-month gap in wind speeds was filled by regression. No outliers or errors (other than a few missing hourly records) were noted in other variables during quality control. We extracted daily minimum relative humidity, maximum wind gust speeds, and 10-hour fuel moistures (Nelson 2000) calculated by FFP5 from the hourly data prescription analysis. The Nelson (2000)

Table 1 Pearson correlation coefficients between Baron and Markleeville remote automated weather stations (RAWS) for the period 2011 to 2019 for daily values of each variable by meteorological season, as part of our study assessing the patterns of potential prescribed burning feasibility in the Lake Tahoe Basin, USA, from 1999 to 2019. Baron RAWS is located in the Lake Tahoe Basin, study area and is sited in Meyers,

California, approximately $10 \mathrm{~km}$ south of Lake Tahoe, but it only included data beginning in mid 2011. Markleeville RAWS is sited in Markleeville, California, approximately $35 \mathrm{~km}$ south southeast of Lake Tahoe and included complete quality data covering the study period 1999 to 2019. Seasonal correlations were measured to assess the appropriateness of using Markleeville RAWS to estimate Baron RAWS variables by regression in order to obtain weather data for the entire 1999 to 2019 study period. Variables tested were those to assess basic climatological site similarity and include average, minimum, and maximum temperature ( $T_{\text {avg }}, T_{\max }, T_{\min }$, respectively); and average, minimum, and maximum relative humidity $\left(\mathrm{RH}_{\text {avg }}, \mathrm{RH}_{\text {min }}, \mathrm{RH}_{\text {max }}\right.$ respectively). Meteorological seasons were winter (1 December to 28 or 29 February), spring (1 March to 31 May), summer (1 July to 31 August), and autumn (1 September to 30 November)

\begin{tabular}{lllllll}
\hline Season & $\mathrm{T}_{\text {avg }}$ & $\mathrm{T}_{\min }$ & $\mathrm{T}_{\max }$ & $\mathrm{RH}_{\mathrm{avg}}$ & $\mathrm{RH}_{\min }$ & $\mathrm{RH} H_{\max }$ \\
\hline Winter & 0.94 & 0.92 & 0.87 & 0.78 & 0.79 & 0.63 \\
Spring & 0.96 & 0.90 & 0.96 & 0.81 & 0.88 & 0.55 \\
Summer & 0.90 & 0.78 & 0.96 & 0.65 & 0.87 & 0.42 \\
Autumn & 0.96 & 0.88 & 0.97 & 0.78 & 0.85 & 0.53 \\
\hline
\end{tabular}

defaults 10 -hour fuel moisture to $25 \%$ when there is snow cover at the RAWS site. To maintain a normal data distribution for the regression, we calculated 10-hour fuel moistures with no snow cover.

We used adjusted data from the Markleeville RAWS to estimate daily minimum relative humidity, 10-hour fuel moisture, and maximum wind gust speed at Baron RAWS prior to August 2011. Data from the period available at both RAWS were divided into training (1 January 2012 to 31 December 2015) and validation (1 January 2016 to 31 Dec 2019) periods. For each variable, we developed a linear regression model between Baron and Markleeville RAWS over the training period and tested it over the validation period. Model fit and validation statistics are shown in Table 2. We then used the regressions to estimate Baron RAWS data for 1 January 1999 through 31 July 2011 from daily Markleeville RAWS data. To evaluate the consistency of local patterns, we applied burn-window analysis separately to the Baron and Markleeville RAWS stations and to three other nearby RAWS: Dog Valley, Stampede, and Little Valley (see Fig. 1 for station locations). This analysis was limited to 2012 to 2019, the full period of overlap. Results for these additional stations are shown in Additional files 1 to 3 .
Table 2 Model results for the regression of Markleeville remote automated weather station (RAWS) variables to estimate Baron RAWS prior to August 2011 when Baron RAWS became operational, as part of our study assessing the patterns of potential prescribed burning feasibility in the Lake Tahoe Basin, USA, from 1999 to 2019. Baron RAWS relative humidity (\%), 10hour fuel moisture (\%), and wind gust speeds $\left(\mathrm{km} \mathrm{hr}^{-1}\right)$ were estimated by simple regression of these variables from Markleeville RAWS in order to obtain weather data from 1 January 1999 to 31 July 2011. Baron RAWS recorded observations were used from 1 August 2011 to December 2019 to provide a complete dataset for the entire study period (1999 to 2019). These data were used to determine if each day was within burn plan prescription criteria. Baron RAWS is located within the Lake Tahoe Basin, in Meyers, California, approximately $10 \mathrm{~km}$ south of Lake Tahoe. Markleeville RAWS is sited in Markleeville, California, approximately $35 \mathrm{~km}$ south southeast of Lake Tahoe. Model Adj. $R^{2}$ train and Adj. $R_{\text {valid }}^{2}$ are coefficients of determination for training ( 1 January 2012 to 31 December 2015) and validation (1 January 2016 to 31 December 2019), respectively. Validation $\mathrm{R}$ is the Pearson correlation coefficient between the modeled and the observed validation data $(P \leq$ 0.001 for all regressions)

\begin{tabular}{llll}
\hline Variable & Adj. $\mathrm{R}_{\text {train }}$ & Adj. $\mathrm{R}_{\text {valid }}$ & Validation $\mathrm{R}$ \\
\hline Relative humidity (\%) & 0.782 & 0.795 & 0.89 \\
10-hour fuel moisture (\%) & 0.691 & 0.753 & 0.87 \\
Wind gust speed $\left(\mathrm{km} \mathrm{hr}^{-1}\right)$ & 0.725 & 0.700 & 0.84 \\
\hline
\end{tabular}




\section{Availability of firefighting resources}

Preparedness level (PL) is a daily index that ranks the commitment level of fire suppression and incident management resources for a geographic area from 1 (low) to 5 (high). PL3 is not a threshold for prescribed fire implementation set by Forest Service policy; we used it in this study as a surrogate indicator of operational and contingency resource availability to add a "reasonable and feasible" element to the analysis, although it may not be a perfect proxy of crew availability. Here we assumed that prescribed burning was feasible at PL1 and PL2, both within and outside of the usual fire season. At PL3, environmental conditions are such that there is high potential for fires greater than 40 hectares to occur, with several fires less than 40 hectares active in the geographic area. The USDA Forest Service et al. (2016) describes PL3 as,

Mobilization of agency and interagency resources is occurring within the geographic area, but minimal mobilization is occurring between or outside of the geographic area. Current and short-term forecasted fire danger is moving from medium to high or very high. Local Units implementing prescribed fire operations are starting to compete for interagency contingency resources.

The Northern California Geographic Area Coordination Center (ONCC) begins preparedness planning for the Northern California Geographic Area (NOPS) by 1 May and continues through at least 15 October (USDA Forest Service et al. 2016). Review of PLs revealed gaps in the NOPS data (primarily in the non-fire season months in 2004 to 2008), but national PL data are complete. National PL and the existing NOPS PL are very similar, so we used NOPS PL preferentially in the analysis, with national PLs used in those instances when NOPS PLs are missing.

\section{Burn-window occurance}

We determined burn windows by assessing when CARB burn days, days meeting burn plan prescription criteria, and NOPS PL $<3$ occurred simultaneously. Burn windows were summarized to identify: (1) how often each day of the year met each criterion individually and all criteria simultaneously; (2) the seasonal frequency of single-day and multi-day burn windows; and (3) interannual variability in burn windows. All analyses (except trend analysis, which was performed in R [R Core Team 2016]) were performed using spreadsheet tools to facilitate wider use of these methods in management settings. We initially assessed changes in annual burn-window frequency using linear regression in R ( $R$ Core Team 2016). Because residuals often were not normally distributed, we tested for trends with the Mann-Kendall trend test (Mann 1945; Kendall 1975; Gilbert 1987) using the Kendall package in the R program (McLeod 2011). When trends were identified in the number of burn windows, we performed trend analysis on the individual variables (CARB burn days, days with $\mathrm{PL}<3$, and days in prescription) to identify the variable or variables driving the trend.

\section{Results}

Burn windows were especially rare during peak fire season (July to September) and also December through January (Figs. 2 and 3). Less than one-third of days in October and in November were burn windows. January and December each had 20\% likelihood of burn windows (Fig. 3). They were most common from February to May and from October through November, but the daily likelihood rarely exceeded $50 \%$ in spring and $40 \%$ in autumn

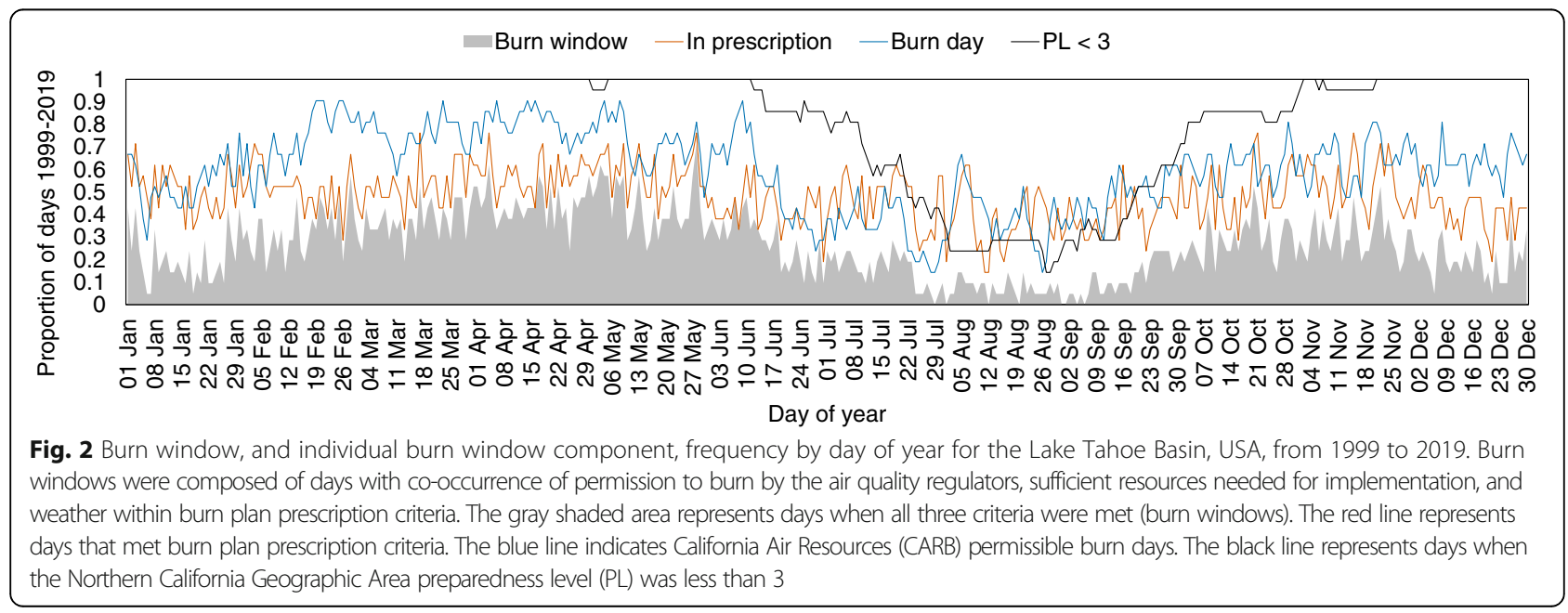




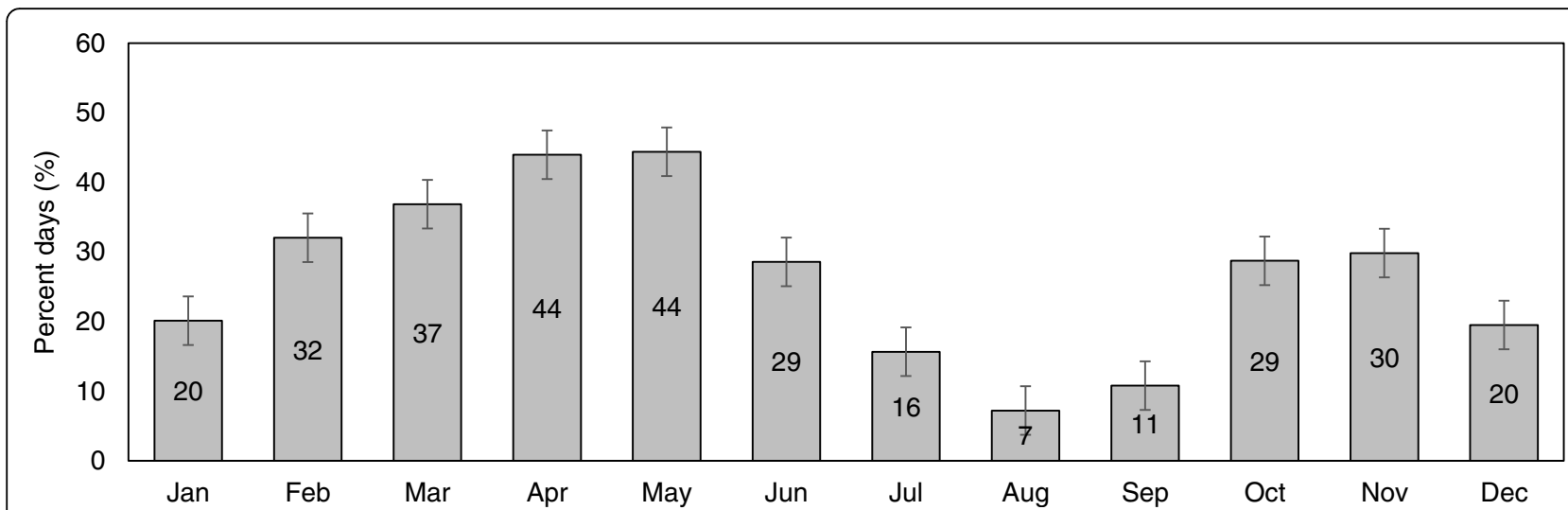

Fig. 3 Percentage of all days in each month that were burn windows in the Lake Tahoe Basin, USA, from 1999 to 2019. Days with simultaneous occurrence of permission to burn by the air quality regulators, sufficient resources needed for implementation, and weather within burn plan prescription criteria were designated as burn windows. Error bars show the standard error of the mean

(Fig 2). Burn-window frequency ranged from a high of 44\% in April and May to a low of 7\% in August (Fig. 3). Nearby stations showed similar seasonal patterns in burn-window occurrence, although the absolute frequency of burn windows differed from station to station, with Dog Valley and Baron RAWS having the most frequent burn days and Markleeville RAWS the fewest (Additional files 1 and 2).

Over the 21-year analysis period, consecutive multiday burn windows were uncommon, and burn windows longer than four consecutive days were very rare. Burn windows lasting two to three days were most common from February through June and October through November, yet there were still, on average, two or fewer two- to three-day burn windows per year in these months (Fig. 4). Slightly longer (four- to five-day) burn windows were most common in April, May, October, and November, but these occurred on average less than once per year (Fig. 4).
Six-day or longer burn windows occurred about once every two years in May and were even rarer in other months (Fig. 4). Multi-day burn windows of any length were rare during the peak fire season (July through September), with just 42 occurrences over 21 years.

Summer had infrequent burn windows, often zero in any given year, especially in August (Fig. 5). August burn windows occurred in only seven of the 21 years studied. July and September each had burn windows in 14 days throughout the study period. May was the most variable month and December the least variable (Fig. 5). In the months from November through May, burn windows occurred in every year, but they were highly variable. In May, for example, there were only two burn windows in 2001, but there were 24 burn windows in both 2010 and 2011. Analysis of more stations over a shorter time frame (2012 to 2019) confirms the high degree of interannual variability in burn windows, particularly in the

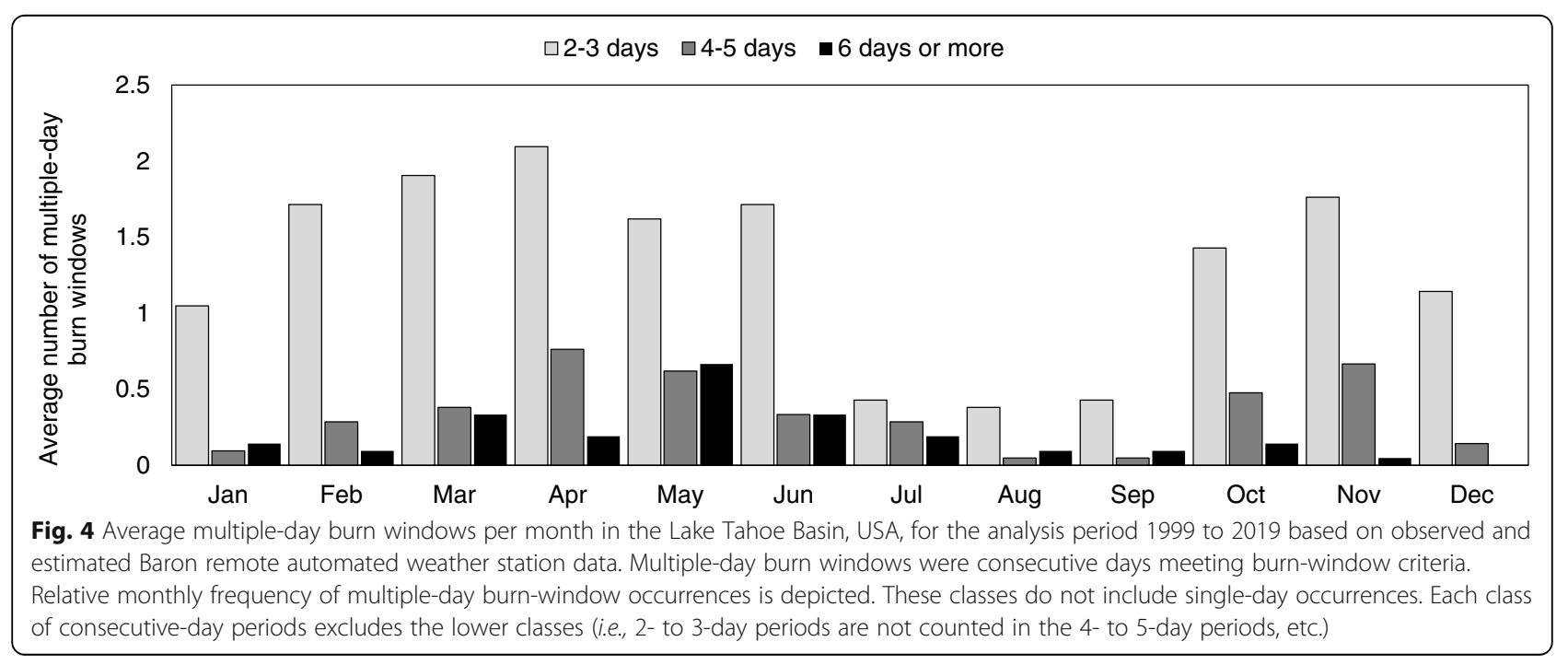




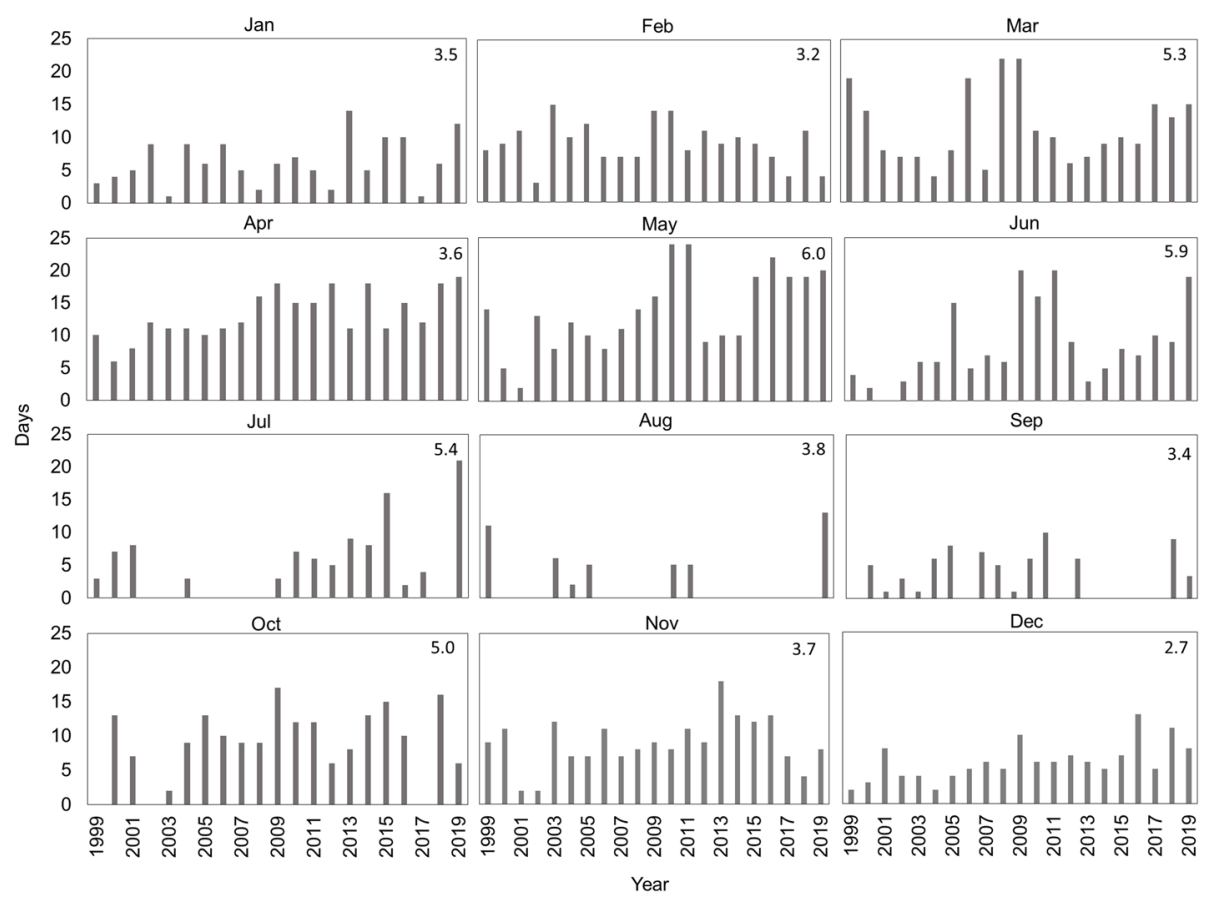

Fig. 5 Monthly burn-window frequency by year for the Lake Tahoe Basin, USA, from 1999 to 2019 based on observed and estimated Baron remote automated weather station data. Interannual standard deviations for each month are shown in the upper right-hand corner of each graph

summer but also in the winter and spring (Additional file 3).

Burn windows-days on which all three criteria are met-were far less common than the number of days meeting any one criterion (Fig. 2). Year-round, burnplan prescription was the most consistently limiting factor, except in January, and occasionally in July through October, when CARB burn days were more limiting (Fig. 2). During peak fire season (July to September), weather on any given day of the year was in prescription less than $60 \%$ of the time. In other months, weather was in prescription on any given day up to $\sim 75 \%$ of the time, but it was rarely over $65 \%$ (Fig. 2). CARB burn days occurred most frequently during late winter and spring (February to May, Fig. 2), although they were also relatively common in October, November, and December. January had relatively few CARB burn days. CARB burn days within the peak fire season (July to September) were also relatively uncommon, generally less than 50\% of the time on any given day of the year. NOPS PL was typically $<3$, except from mid July through September (Fig. 2), when fire activity in the NOPS geographic area usually peaks and firefighting resources are committed to ongoing incidents. While NOPS PL was rarely limiting, it was the most limiting factor about $25 \%$ of the time during August through mid September.

Annual burn-window frequency (Fig. 6) increased significantly over our analysis (Mann-Kendall $\tau=0.438$, 2-sided $P=0.006)$. CARB burn days was the only variable with a significant trend (Mann-Kendall $\tau=$ 0.616, 2 -sided $P \leq 0.001$ ). An abrupt increase in CARB burn day frequency occurred around 2008 (Fig. 6), raising the question of whether the trend had a physical basis. The primary criterion used in burn-day decisions by CARB is 500 -hectopascal $(\mathrm{hPa})$ geopotential height, assuming that air quality is not already low (D. Mims, personal communication, 2019). Higher geopotential height (ridging) indicates higher pressure and typically warmer and drier conditions. Conversely, lower geopotential heights are associated with cooler and often stormier conditions. A positive trend in burn days would imply lower $500 \mathrm{hPa}$ heights (i.e., less ridging), cooler temperatures, and likely more precipitation, but coolseason ridging has in fact increased since the middle of the twentieth century (Swain et al. 2016). A CARB meteorologist (D. Mims, personal communication, 2017) stated that, in 2008, mixing heights and transport winds were given increased weight in burn-day decisions for the Lake Tahoe Air Basin, rather than relying as strongly on $500 \mathrm{hPa}$ height. Thus, the positive trend in burn windows was not due to shifting meteorological conditions, but to a regulatory change.

\section{Discussion}

In frequent-fire (FR1) forests of the western USA, fire is a critically important ecological process that has been 
greatly reduced by human management, leading to degraded ecological conditions. Much of the yellow pinemixed conifer forest is at increased risk of uncharacteristically large, high-severity wildfires (Westerling et al. 2006; Miller et al. 2009; Safford and Stevens 2017). Forest restoration and fuel hazard reduction activities are implemented to reduce this risk (Ritchie et al. 2007; North et al. 2009; Safford et al. 2012b; McIver et al. 2013). Although the restoration of fire itself (rather than its replacement through surrogates) has been described as a key component of such restoration and hazard reduction programs (Agee and Skinner 2005; Ritchie et al. 2007; North et al. 2009; Stephens et al. 2009; Vaillant and Stephens 2009; McIver et al. 2013), there are numerous challenges in applying prescribed fire broadly. Given these challenges, establishing and maintaining a prescribed fire program that will meet restoration and hazard reduction objectives requires flexibility and an understanding of burn-window patterns and inherent uncertainty.

Our study shows that the annual frequency of burn windows in the LTB follows a general pattern, with the greatest likelihood in spring followed by autumn (Figs. 2 and 3). Summer has the fewest burn windows of any season, but conditions during some summers may be suitable to meet objectives on small spatial scales (e.g., 2019; Fig. 5). Autumn burn windows were somewhat less frequent than spring. While burn windows are less frequent in autumn than they are in the spring, managers often plan to conduct more complex prescribed understory burns in autumn because, (1) the historical fire season in the Sierra Nevada region was mostly summer through autumn, but summer has few burn windows; and 2) autumn precipitation events can assist with controlling prescribed fires, reducing the chance of fire escape (Fettig et al. 2010). Moreover, fuel moisture is typically lower in autumn than in spring, so if maximum fuel consumption is the chief objective, late-season burns will be more effective (Knapp et al. 2005). If increasing forest heterogeneity or maintaining litter and duff layers are key objectives, higher fuel moisture in spring facilitates creating a patchier residual surface-fuel pattern (Knapp et al. 2005; Knapp and Keeley 2006). Since burn windows are most prevalent in the spring, taking advantage of those opportunities could help to better meet fuels and restoration program goals.

In areas with a predominantly late-season fire regime, however, many species may not be adapted to earlyseason burning if the historical regime was one of predominantly summer to early fall fire (Knapp et al. 2007), and the ecological impacts of spring fires are not well understood. For example, Harrington (1993) and Thies et al. (2005) found that ponderosa pine (Pinus ponderosa Dougl. ex Laws.) mortality was greater after autumn than spring burns in Colorado and Oregon, USA, but Schwilk et al. (2006) found no significant difference in overstory tree mortality between early- and late-season burning in the southern Sierra Nevada. Fettig et al. (2010) measured higher mortality of large trees after spring burns. Few studies have focused on the long- and short-term effects of spring burning on understory plant and animal species in montane forests. Kerns et al. (2006) found decreased prevalence of exotic species after early-season burns. Knapp et al. (2007) found lower impacts to understory perennial species, but impacts appeared to be more related to fire intensity than to season, per se.

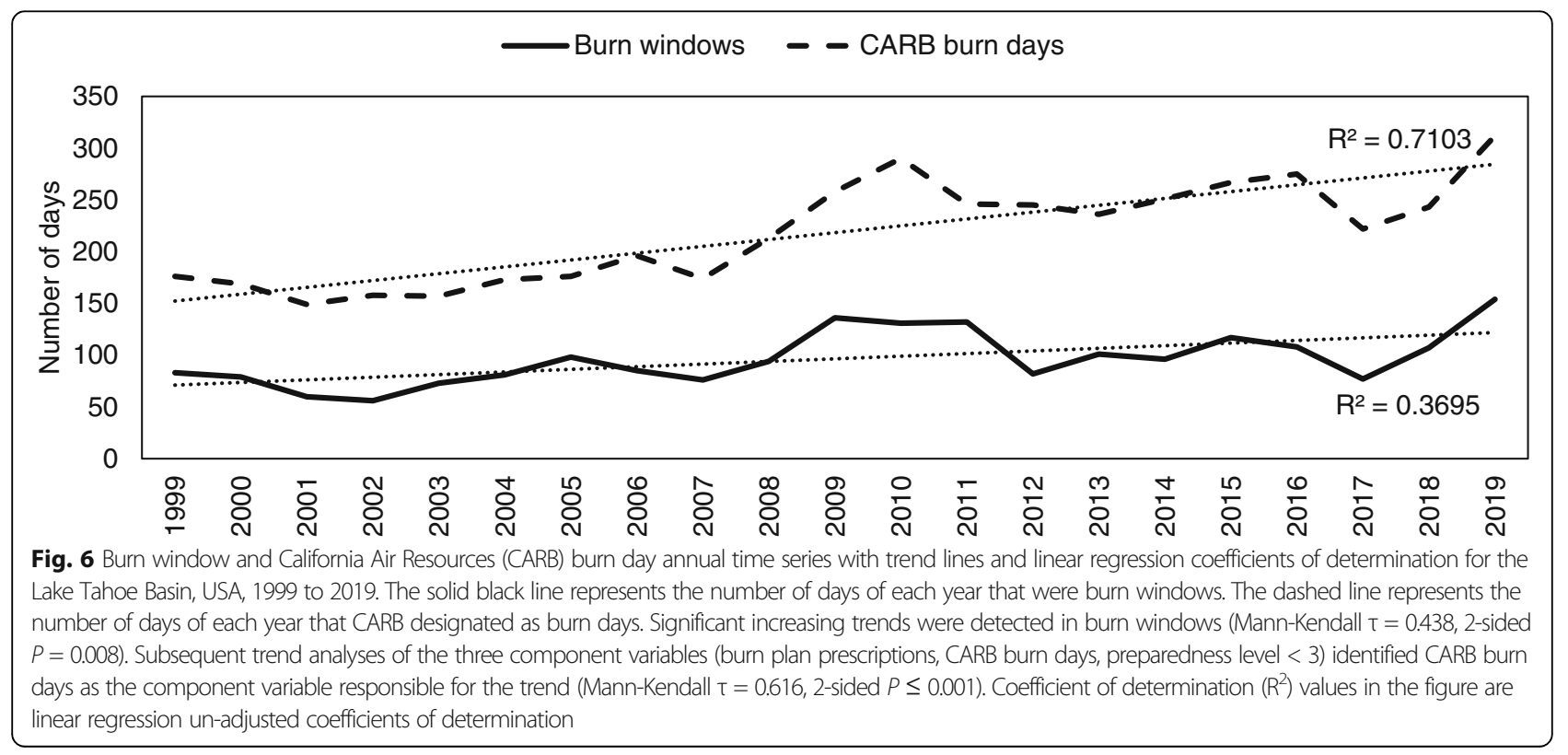


Burn windows were also reasonably common in the winter (Figs. 2 and 3). Winter burning can be limited due to the occurrence of inversions that trap smoke at low altitudes, degrading air quality. Topographic basins and valleys like the LTB are especially prone to winter inversions under high-pressure conditions, when lower atmosphere mixing is attenuated (Blandford et al. 2008; Wang et al. 2015). Regardless, large parts of the LTB are snow covered in most winters. Although snow cover was not considered in prescription criteria here, it inhibits most burning (pile burning can occur if piles are exposed and accessible). During recent droughts, however, some parts of the LTB were snow free for much of the winter (e.g., 2013, 2015). Burning could be accomplished during burn windows in such drought years. If snowfree or low-snow winters become more common in the future, as some studies suggest (Hayhoe et al. 2004; Knowles et al. 2006; Cayan et al. 2008), prescribed burning may become increasingly possible during winter. As with spring burning, the ecological ramifications of winter burns are not well understood. Research on prescribed burns during the winter and spring will help to characterize the advantages and disadvantages of burning during seasons or conditions outside current management practice and the historical fire season.

There were no significant trends in annual burnwindow frequency once the effect of CARB's policydriven increase in burn days was removed. CARB altered burn day determination criteria in 2008 in response to requests by LTB land managers following the destructive Angora Fire in 2007, in order to increase fire-hazard reduction opportunities using prescribed fire (D. Mims, personal communication, 2017). Because of data limitations, we did not examine when prescribed fires were implemented over the full period of this analysis, but rather those days when prescribed fire could have been implemented based on our criteria. As a result, we do not know if the additional burn days were utilized, but the trend in burn windows associated with a change in burn day criteria demonstrates that reasonable regulatory changes can increase opportunities to implement prescribed burning.

Historical studies indicate that montane forests of the LTB supported frequent fires before the arrival of EuroAmericans (Taylor 2004; Maxwell et al. 2014), with hundreds to thousands of hectares burning per year (Manley et al. 2000). This fire frequency and extent are proportionate to forest fire regimes throughout much of the Sierra Nevada. Between 2010 and 2018 (2014 data are missing), burn logs for the LTB Management unit indicate that the USDA Forest Service treated about 323 ha per year in the LTB, utilizing about 51 burn windows in each year, averaging roughly 6.4 ha per day. The fewest burn windows (34) were exploited in 2013 and the most
(81 burn windows) in 2010. Average area burned per burn window ranged from 3.0 ha per burn window in 2012 to 12.4 ha per burn window in 2018. Prescribed burns averaged about 4.7 ha in size and individual burns rarely exceeded 80 ha (although burning adjacent units could function as a single larger fire). Thus, treated areas were typically notably smaller than historical fires, which are thought to have averaged about 200 to 400 hectares in size in this part of the Sierra Nevada (Safford and Stevens 2017).

On average, there were 96 burn windows each year in the LTB. To attain Manley et al.'s (2000) (probably conservative) estimate of $\sim 800$ hectares burned in an average year before 1850, managers would need to burn an average of 8.5 hectares during each burn window. They currently burn at a rate slightly below 7 ha per burn window and utilize, on average, just over half of the available burn windows. This suggests either that it is not possible to use all available burn windows and routinely treat 8.5 ha per burn window with current resources and risk tolerance, or that there may be additional constraints on burning that were not considered here. Although our analysis suggests that resources are usually not a limiting factor (Fig. 2), PL is an imperfect proxy. It is designed to assess wildfire readiness and not the capacity to conduct prescribed burns. Because the fire season is concentrated during the summer months, the temporary workforce is often reduced during spring and autumn, decreasing resource availability for forest management activities at a time when burn windows, and particularly multi-day burn windows, are more common (Figs. 2, 3, 4).

Increasing staffing during the spring and autumn would appear to be a reasonable response, particularly because it might allow for larger burns on days when managers can burn. However, interannual variability in burn-window frequency is high during those seasons (Fig. 5), creating challenges for managers who want to take advantage of periods when burn windows are frequent, yet reduce costs associated with keeping crews on payroll when burning opportunities do not occur. Exploring relationships between burn-window patterns and large-scale climatic drivers (e.g., El Niño Southern Oscillation) could help better forecast burnwindow availability in upcoming seasons and potentially reduce uncertainty for managers. Developing innovative crew staffing programs may be required to meet these challenges. Forest Service Region 5 is currently transitioning to a unified program of work for all national forests in its region, entitled One Region, One Program of Work (USDA Forest Service Pacific Southwest Region 2019). This encourages sharing of crews, personnel with needed skills, and resources across units to meet management goals in the face of changing climate, declining budgets, and shrinking staffs. Other options include interagency crews formed through state, local, and 
federal partnerships that could help ease the financial burden while recognizing fuels reduction and restoration priorities, and multi-resource management crews that are prescribedfire qualified but can also be used for other types of work. The recent institution of year-round, full-time prescribed fire teams by CAL FIRE, some of which are stationed near the LTB, may be a catalyst for this sort of collaborative work.

If resource availability cannot be increased, the other option is to increase the number of available burn windows by introducing greater flexibility in air quality or prescriptive standards. Such flexibility was demonstrated by CARB when it changed burn-day determination criteria for the LTB in 2008, significantly increasing the number of burn windows. Since days in prescription are less frequent than other criteria studied here, practices that relax some prescriptive criteria may be especially helpful. One possibility is a matrix approach to prescriptions in which parameters offset each other (e.g., low dead fuel moisture is offset by high live fuel moisture, or lower fuel moisture and humidity are offset by low wind speeds; Raybould and Roberts 2006). Permitting higher levels of tree mortality in prescribed fires would also allow greater flexibility in burn prescriptions. Current prescribed fire prescriptions are often designed to minimize overstory mortality. However, even lowseverity burning in wildfires can kill $20 \%$ or more of affected trees, and it has been suggested that prescribed fires should aim to better mimic the impacts of historical wildfires, for example by permitting higher mortality levels in canopy trees (Safford et al. 2012b).

Retrospective analyses like this provide a tool to evaluate multiple concurrent constraints on prescribed burning can also be used to test the effectiveness of staffing and regulatory changes. If managers compare available and actual burn windows and find that they are not exploiting burn windows in the early spring or late autumn due to resource issues, they could plan short extensions to some seasonal hire terms. By applying different prescriptive criteria to the weather data used here and evaluating how those criteria influence the number and timing of burn windows, managers could identify when modest changes to prescription criteria would expand burn windows most conducive to meeting management goals. This tool could also be used, in collaboration with air quality regulators, to detect times of year when otherwise multi-day burn windows are truncated by no-burn days and assess the costs and benefits of additional regulatory changes. Multi-day burn windows would allow larger burn projects to be completed.

\section{Conclusions}

Forest managers navigate a complex system of environmental, policy, and regulatory requirements, as well as consider public opinion, to plan and implement prescribed fires (Quinn-Davidson and Varner 2012; Ryan et al. 2013; North et al. 2015a, b; Kolden 2019). Weather and resource limitations like those investigated here constrain managers' ability to meet restoration objectives with prescribed fire (Quinn-Davidson and Varner 2012; North et al. 2015b). Given the importance of prescribed fire and the myriad constraints to its implementation, managers need tools to help reduce uncertainty when planning fuels-management programs. This study may assist forest managers in planning and prioritizing prescribed fire programs by quantifying constraints and opportunities and identifying areas for managementrelevant research.

Prescribed fire is an important tool for restoring FR1 forests and reducing fuels loads, but its current use on the ground in the western USA is making a vanishingly small contribution to reducing the fire deficit (North et al. 2012; Quinn-Davidson and Varner 2012; North et al. 2015a; Kolden 2019). Using methods that are easily applicable to other management units operating under similar regulatory regimes, we showed that (1) burn windows occur infrequently; (2) multi-day burn windows are rare; and (3) there is high interannual variability in burn window occurrence, particularly in the spring and autumn. These conditions characterize much of the western USA and challenge managers trying to plan efficient and effective burning programs.

Considering the limitations to prescribed fire implementation can also help managers and regulators identify modest changes-like those implemented by CARB in the LTB-that can enhance prescribed burning opportunities. Quantitative assessment of prescribed burning opportunities is particularly important now because the fire season is growing in length (Westerling et al. 2006; Jolly et al. 2015), and the periods preferred for prescribed burning are shifting earlier in the spring and later in the fall, when seasonal staffing is often reduced and the ecological consequences of prescribed fire are less well understood. Analyzing historical burn window patterns and the factors that constrain them can help managers pinpoint optimal periods in the calendar that are most likely to provide opportunities to burn safely, efficiently, and sustainably.

\section{Supplementary information}

Supplementary information accompanies this paper at https://doi.org/10. 1186/s42408-020-00071-3.

Additional file 1. Percent each day of the year was a burn window from 2012 to 2019 for Baron remote automated weather station (RAWS; elevation $1931 \mathrm{~m}$ ) and four comparable RAWS nearby at similar elevations and forest types, but outside the Lake Tahoe Basin, USA. Burn windows for our study assessing the patterns of potential prescribed burning feasibility in the Lake Tahoe Basin, from 1999 to 2019, were designated as days with simultaneous occurrence of weather within burn 
plan prescription criteria, sufficient resources for implementation, and permission from air quality regulators to burn. The general burn-window frequency pattern exhibited at Baron RAWS is consistent overall: highest frequencies in spring and autumn, lowest during summer. Markleeville RAWS (elevation 1676 m) and Little Valley RAWS (elevation 1920 m) tended to have higher burn-window frequencies in winter, while Stampede RAWS (elevation $1891 \mathrm{~m}$ ) tended to have the lowest. Dog Valley RAWS (elevation $1821 \mathrm{~m}$ ) had highest frequencies in March and April. These burn-window frequencies reflect differences in the weathergenerated prescription variables (relative humidity, 10-hour fuel moisture, and wind gust speeds).

Additional file 2. Percent days for each month that met burn-window criteria from 2012 to 2019 for Baron remote automated weather station (RAWS) and four comparable RAWS nearby, but outside the Lake Tahoe Basin, USA. Burn windows for our study assessing the patterns of potential prescribed burning feasibility in the Lake Tahoe Basin, from 1999 to 2019, were composed of days with co-occurrence of permission to burn by the air quality regulators, sufficient resources needed for implementation, and weather within burn plan prescription criteria. Monthly burnwindow frequencies for each RAWS are shown for comparison. The general burn-window frequency pattern exhibited at Baron RAWS is consistent overall: highest frequencies in spring and autumn, lowest during summer. Little Valley RAWS had the highest frequencies and Stampede RAWS had the lowest during winter (December to February). As with daily frequencies (Additional file 1), Dog Valley RAWS had highest frequencies in March and April, and second only to Baron RAWS in May and June. Markleeville RAWS had lowest frequencies April to November.

Additional file 3. Annual burn-window frequency by month for four remote automated weather station (RAWS) compared to Baron RAWS, in the Lake Tahoe Basin and surrounding region, USA. Days with simultaneous occurrence of permission to burn by the air quality regulators, sufficient resources needed for implementation, and weather within burn plan prescription criteria were designated as burn windows for our study assessing the patterns of potential prescribed burning feasibility in the Lake Tahoe Basin, from 1999 to 2019. The seasonal patterns exhibited for daily and monthly frequencies generally apply (e.g., low frequencies in summer and highest frequencies in spring). However, a high degree of annual variation is apparent. Notable is the consistency between stations for relatively high burn-window frequency during summer 2019, as well as July 2015.

\section{Acknowledgements}

Not applicable.

\section{Authors' contributions}

RS and MP developed the basic methodology and conducted the data analysis. RS, HS, and SM contributed to the manuscript. All authors read and approved the final manuscript.

\section{Funding}

Work on the project was carried out as part of the authors' employment and RS's graduate studies and was not funded by any specific grant or contract.

\section{Availability of data and materials}

The corresponding author will provide data and the Excel spreadsheet used for calculation upon request.

\section{Ethics approval and consent to participate}

Not applicable.

\section{Consent for publication}

Not applicable.

\section{Competing interests}

The authors declare they have no competing interests.

\section{Author details}

'USDA Forest Service, Pacific Southwest Region, 1323 Club Drive, Vallejo, California 94592, USA. ${ }^{2}$ Department of Geography, University of Nevada, Reno, 1664 North Virginia Street, Reno, Nevada 89557, USA. ${ }^{3}$ Nevada State
Climate Office and University of Nevada Extension, 1664 North Virginia Street, Reno, Nevada 89557, USA. ${ }^{4}$ Department of Environmental Science and Policy, University of California, One Shields Avenue, Davis, California 95616, USA. ${ }^{5}$ USDA Forest Service, National Forest in Florida, Ocala National Forest, 40929 State Road 19, Umatilla, Florida 32784, USA.

Received: 8 October 2019 Accepted: 22 April 2020

Published online: 25 May 2020

\section{References}

Abatzoglou, J.T., and A.P. Williams. 2016. Impact of anthropogenic climate change on wildfire across western US Forests. Proceedings of the National Academy of Sciences 42: 11770-11775 www.pnas.org/cgi/doi/10.1073/pnas.16 07171113. https://doi.org/10.1073/pnas.1607171113.

Agee, J.K., W.H. Romme, J.F. Franklin, M.D. Hurteau, S.L. Stephens, N. Johnson, T.W. Swetnam, P. Morgan, J. van Wagtendonk. 2016. Letter to EPA, USDA, USDOI, CEQ: The Fire Challenge: Increasing Fire Use for Natural Resource Benefits, Carbon Stability and Protection of Public Health. Letter to EPA, USDA, USDOI, CEQ. https://doi.org/10.1017/CBO9781107415324.004

Agee, J.K., and C.N. Skinner. 2005. Basic principles of forest fuel reduction treatments. Forest Ecology and Management 211: 83-96. https://doi.org/10. 1016/j.foreco.2005.01.034.

Barbour, M.G., E. Kelley, P. Maloney, D. Rizzo, E. Royce, and J. Fites-Kaufmann. 2002. Present and past old-growth forests of the Lake Tahoe Basin, Sierra Nevada, US. Journal of Vegetation Science 13: 461-472. https://doi.org/10. 1658/1100-9233(2002)013[0461:PAPOGF]2.0.CO;2 https://doi.org/10.1111/j. 1654-1103.2002.tb02073.x.

Beaty, R.M., and A.H. Taylor. 2008. Fire history and the structure and dynamics of a mixed conifer forest landscape in the northern Sierra Nevada, Lake Tahoe Basin, California, USA. Forest Ecology and Management 255: 707-719. https:// doi.org/10.1016/j.foreco.2007.09.044.

Blandford, T.R., K.S. Humes, B.J. Harshburger, B.C. Moore, V.P. Walden, and H. Ye. 2008. Seasonal and synoptic variations in near-surface air temperature lapse rates in a mountainous basin. Journal of Applied Meteorology and Climatology 47: 249-261. https://doi.org/10.1175/2007JAMC1565.1.

Bradshaw, Larry, and Erin McCormick. 2000. FireFamily Plus user's guide, Version 2.0. Gen. Tech. Rep. RMRS-GTR-67. Ogden: U.S. Department of Agriculture, Forest Service, Rocky Mountain Research Station https://doi.org/10.2737/RMRS-GTR-67.

California. 2010. California Code of Regulations Title 17, subchapter 2. Smoke management guidelines for agricultural and prescribed burning. https://ww3. arb.ca.gov/regs/regs-17.htm

California Department of Forestry and Fire Protection, California State Parks, California Tahoe Conservancy, Fallen Leaf Fire Department, Lake Valley Fire Protection District, Meeks Bay Fire Protection District, Nevada Division of Forestry, Nevada Division, USDA Forest Service. 2014. Lake Tahoe Basin MultiJurisdictional Fuel Reduction and Wildfire Prevention Strategy.

Cayan, D.R., E.P. Maurer, M.D. Dettinger, M. Tyree, and K. Hayhoe. 2008. Climate change scenarios for the California region. Climatic Change 87: 21-42 https:// doi.org/10.1007/s10584-007-9377-6.

Elliott-Fisk, D.L., T.C. Cahill, O.K. Davis, L. Duan, C.R. Goldman, G.E. Gruell, R. Harris, R. Kattelmann, R. Lacey, D. Leisz, S. Lindstrom, D. Machida, R.A. Rowntree, P. Rucks, D.A. Sharkey, S.L. Stephens, and D.S. Zeigler. 1997. Lake Tahoe case study. Sierra Nevada Ecosystem Project Final Report to Congress. Addendum. University of California, Davis, Centers for Water and Wildland Resources.

Estes, B.L., E.E. Knapp, C.N. Skinner, and F.C.C. Uzoh. 2012. Seasonal variation in surface fuel moisture between unthinned and thinned mixed conifer forest, northern California, USA. International Journal of Wildland Fire 21: 428-435 https://doi.org/10.1071/WF11056.

Fettig, C.J., S.R. McKelvey, D.R. Cluck, S.L. Smith, and W.J. Otrosina. 2010. Effects of prescribed fire and season of burn on direct and indirect levels of tree mortality in Ponderosa and Jeffrey Pine Forests in California, USA. Forest Ecology and Management 260: 207-218. https://doi.org/10.1016/j.foreco.2010. 04.019.

Gilbert, R.O. 1987. Statistical Methods for Environmental Pollution Monitoring. NY: Wiley.

Hardy, C.C., K.M. Schmidt, J.M. Menakis, and N.R. Samson. 2001. Spatial data for national fire planning and fuel management. International Journal of Wildland Fire. 10: 353-372 https://doi.org/10.1071/WF01034.

Harrington, M. 1993. Mortality from dormant season and growing-season fire injury. International Journal of Wildland Fire 3: 65-72. https://doi.org/10.1071/ WF9930065. 
Hayhoe, K., D. Cayan, C.B. Field, P.C. Frumhoff, E.P. Maurer, N.L. Miller, and J.H. Verville. 2004. Emissions pathways, climate change, and impacts on California. Proceedings of the National Academy of Sciences 101: 12422-12427 https://doi.org/10.1073/pnas.0404500101.

Holden, Z.A., A. Swanson, C.H. Luce, W.M. Jolly, M. Maneta, J.W. Oyler, D.A. Warren, R. Parsons, and D. Affleck. 2018. Decreasing fire season precipitation increased recent western US forest wildfire activity. Proceedings of the National Academy of Sciences 115: E8349-E8357 www.pnas.org/cgi/doi/10.1 073/pnas.1802316115. https://doi.org/10.1073/pnas.1802316115.

Jolly, W.M., M.A. Cochrane, P.H. Freeborn, Z.A. Holden, T.J. Brown, G.J. Williamson, and D.M.J.S. Bowman. 2015. Climate-induced variations in global wildfire danger from 1979 to 2013. Nature Communications 6: 7537 https://doi.org/ 10.1038/ncomms8537.

Kendall, M.G. 1975. Rank Correlation Methods. 4th ed. London: Charles Griffin.

Kerns, B.K., W.G. Thies, and C.G. Niwa. 2006. Season and severity of prescribed burn in ponderosa pine forests: implications for understory native and exotic plants. Ecoscience 13: 44-55 https://doi.org/10.2980/1195-6860(2006)13[44: SASOPB]2.0.CO;2.

Kilgore, B.M., and R.W. Sando. 1975. Crown-fire potential in a sequoia forest after prescribed burning. Forest Science 21: 83-87 https://doi.org/10.1093/ forestscience/21.1.83

Knapp, E.E., and J.E. Keeley. 2006. Heterogeneity in fire severity within early season and late season prescribed burns in a mixed-conifer forest. International Journal of Wildland Fire 15: 37-45 https://doi.org/10.1071/ WF04068.

Knapp, E.E., J.E. Keeley, E.A. Ballenger, and T.J. Brennan. 2005. Fuel reduction and coarse woody debris dynamics with early season and late season prescribed fire in a Sierra Nevada mixed conifer forest. Forest Ecology and Management 208: 383-397 https://doi.org/10.1016/j.foreco.2005.01.016.

Knapp, E.E., D.W. Schwilk, J.M. Kane, and J.E. Keeley. 2007. Role of burning season on initial understory vegetation response to prescribed fire in a mixed conifer forest. Canadian Journal of Forest Research 37: 11-22 https://doi.org/ 10.1139/x06-200.

Knowles, N., M. Dettinger, and D. Cayan. 2006. Trends in snowfall versus rainfall in the western United States. Journal of Climate 19: 4545-4559 https://doi.org/ 10.1175/JCLI3850.1.

Kolden, C.A. 2019. We're not doing enough prescribed fire in the western United States. Fire 2: 30 https://doi.org/10.3390/fire2020030.

LTBMU. 2015. Lake Tahoe Basin Management Unit Visitor Use Monitoring Report

Mallek, C.R., H.D. Safford, J.H. Viers, and J. Miller. 2013. Modern departures in fire severity and area vary by forest type, Sierra Nevada and southern Cascades, California, USA. Ecosphere 4: 153 https://doi.org/10.1890/ES13-00217.1.

Manley, P.N., J.A. Fites-Kaufman, M.G. Barbour, M.D. Schlesinger, and D.M. Rizzo. 2000. Biological Integrity. In Lake Tahoe watershed assessment: Volume I. PSW-GTR-175, ed. D.D. Murphy and C.M. Knopp, 403-600. Albany: US Dept. of Agriculture, Forest Service, Pacific SW Research station.

Mann, H.B. 1945. Non-parametric tests against trend. Econometrica 13: 163-171 https://doi.org/10.2307/1907187.

Maxwell, R., A. Taylor, C. Skinner, H. Safford, R. Isaacs, C. Airey, and A. Young. 2014. Landscape-scale modeling of reference period forest conditions and fire behavior on heavily logged lands. Ecosphere 5: 32. https://doi.org/10.1890/ ES13-00294.1.

Mclver, J.D., S.L. Stephens, J.K. Agee, J. Barbour, R.E.J. Boerner, C.B. Edminster, K.L. Erickson, K.L. Farris, C.J. Fettig, C.E. Fiedler, S. Haase, S.C. Hart, J.E. Keeley, E.E. Knapp, J.F. Lehmkuhl, J.J. Moghaddas, W. Otrosina, K.W. Outcalt, D.W. Schwilk, C.N. Skinner, T.A. Waldrop, C.P. Weatherspoon, D.A. Yaussy, A. Youngblood, and S. Zack. 2013. Ecological effects of alternative fuel-reduction treatments: Highlights of the National Fire and Fire Surrogate study (FFS). International Journal of Wildland Fire 22: 63-82. https://doi.org/10.1071/WF11130

McLeod, A.I. 2011. Kendall: Kendall rank correlation and Mann-Kendall trend test.

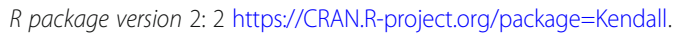

Miller, J.D., H.D. Safford, M. Crimmins, and A.E. Thode. 2009. Quantitative Evidence for Increasing Forest Fire Severity in the Sierra Nevada and Southern Cascade Mountains, California and Nevada, USA. Ecosystems 12: 16-32. https://doi.org/ 10.1007/s10021-008-9201-9.

Nagel, T.A., and A.H. Taylor. 2005. Fire and persistence of montane chaparral in mixed conifer forest landscapes in the northern Sierra Nevada, Lake Tahoe Basin, California, USA. The Journal of the Torrey Botanical Society 132: 442-457 https://doi.org/10.3159/1095-5674(2005)132[442:FAPOMC]2.0.CO;2.
National Wildfire Coordinating Group. 2017. Interagency Prescribed Fire Planning and Implementation Procedures Guide. PMS 484-1. https://www.nwcg.gov/ publications/484

Nelson, R.M.J. 2000. Prediction of diurnal change in 10-h fuel stick moisture content. Canadian Journal of Forest Research 30: 1071-1087. https://doi.org/ 10.1139/x00-032.

North, M., A. Brough, J. Long, B. Collins, P. Bowden, D. Yasuda, J. Miller, and N. Sugihara. 2015a. Constraints on mechanized treatment significantly limit mechanical fuels reduction extent in the Sierra Nevada. Journal of Forestry 113: 40-48. https://doi.org/10.5849/jof.14-058.

North, M., B.M. Collins, and S. Stephens. 2012. Using fire to increase the scale, benefits, and future maintenance of fuels. Journal of Forestry 110: 392-401 https://doi.org/10.5849/jof.12-021.

North, M., S. Stephens, B. Collins, J. Agee, G. Aplet, J. Franklin, and P.Z. Fulé. 2015b. Reform forest fire management: Agency incentives undermine policy effectiveness. Science 349: 1280-1281. https://doi.org/10.1126/science. aab2356

North, M., P. Stine, K.O. Hara, W. Zielinski, and S.L. Stephens. 2009. An Ecosystem Management Strategy for Sierran Mixed-Conifer Forests, General Technical Report PSW-GTR-220, 49. Albany: U.S. Department of Agriculture, Forest Service, Pacific Southwest Research Station https://doi.org/10.2737/PSW-GTR-220.

Quinn-Davidson, L.N., and J.M. Varner. 2012. Impediments to prescribed fire across agency, landscape and manager: An example from northern California. International Journal of Wildland Fire 21: 210-218. https://doi.org/10. 1071/WF11017.

R Core Team. 2016. R: A language and environment for statistical computing. Vienna: R Foundation for Statistical Computing https://www.R-project.org/.

Raybould, S., and T. Roberts. 2006. A matrix approach to fire prescription writing. Fire Management Today 66: 79-82.

Ritchie, M.W., C.N. Skinner, and T.A. Hamilton. 2007. Probability of tree survival after wildfire in an interior pine forest of northern California: Effects of thinning and prescribed fire. Forest Ecology and Management 247: 200-208. https://doi.org/10.1016/j.foreco.2007.04.044

Ryan, K.C., E.E. Knapp, and J.M. Varner. 2013. Prescribed fire in North American forests and woodlands: history, current practice, and challenges. Frontiers in Ecology and the Environment 11.s1: e15-e24 https://doi.org/10.1890/120329.

Safford, H.D., M.P. North, and M.D. Meyer. 2012a. Climate change and the relevance of historical forest conditions. In Managing Sierra Nevada forests. General Technical Report PSW-GTR-237, ed. M.P. North, 23-46. Albany: USDA Forest Service Pacific Southwest Research Station.

Safford, H.D., and J.T. Stevens. 2017. Natural Range of Variation (NRV) for yellow pine and mixed conifer forests in the Sierra Nevada, southern Cascades, and Modoc and Inyo National Forests, California, USA. General Technical Report PSW-GTR-256, 229. Albany: U.S. Department of Agriculture, Forest Service, Pacific Southwest Research Station.

Safford, H.D., J.T. Stevens, K. Merriam, M.D. Meyer, and A.M. Latimer. 2012b. Fuel treatment effectiveness in California yellow pine and mixed conifer forests. Forest Ecology and Management 274: 17-28 https://doi.org/10.1016/j.foreco. 2012.02.013.

Schmidt, K.M., J.P. Menakis, C.C. Hardy, W.J. Hann, and D.L. Bunnell. 2002. Development of Coarse-Scale Spatial Data for Wildland Fire and Fuel Management. General Technical Report RMRS-87. Fort Collins: U.S. Department of Agriculture, Forest Service, Rocky Mountain Research Station. 41 p. + CD https://doi.org/10.2737/RMRS-GTR-87.

Schwilk, D.W., E.E. Knapp, S.M. Ferrenberg, J.E. Keeley, and A.C. Caprio. 2006. Tree mortality from fire and bark beetles following early and late season prescribed fires in a Sierra Nevada mixed-conifer forest. Forest Ecology and Management 232: 36-45. https://doi.org/10.1016/j.foreco. 2006.05.036

Skinner, C.N., and C.-R. Chang. 1996. Fire Regimes, Past and Present, Sierra Nevada Ecosystem Project: Final report to Congress, vol. II, Assessments and scientific basis for management options. Davis: University of California, Centers for Water and Wildland Resources.

State of California. 2020. California Climate Investments. Prescribed Fire Program. http://www.caclimateinvestments.ca.gov/prescribed-fire. Accessed 8 Mar 2020

Stephens, S.L., J.D.M. Mclver, R.E.J. Boerner, C.J. Fettig, J.B. Fontaine, B.R. Hartsough, P.L. Kennedy, and D.W. Schwilk. 2012. The effects of forest fuelreduction treatments in the United States. Bioscience 62: 549-560. https://doi. org/10.1525/bio.2012.62.6.6. 
Stephens, S.L., and J.J. Moghaddas. 2005. Fuel treatment effects on snags and coarse woody debris in a Sierra Nevada mixed conifer forest. Forest Ecology and Management 214: 53-64. https://doi.org/10.1016/j.foreco.2005.03.055.

Stephens, S.L., J.J. Moghaddas, C. Edminster, C.E. Fiedler, S. Haase, M. Harrington, J.E. Keeley, E.E. Knapp, J.D. Mclver, K. Metlen, C.N. Skinner, E. Fiedler, and M. Hall. 2009. Fire treatment effects on vegetation structure, fuels, and potential fire severity in western U.S. forests. Ecological Applications 19: 305-320 https:// doi.org/10.1890/07-1755.1.

Swain, D.L., D.E. Horton, D. Singh, and N.S. Diffenbaugh. 2016. Trends in atmospheric patterns conducive to seasonal precipitation and temperature extremes in California. Science Advances 2: e1501344. https://doi.org/10.1126/ sciadv. 1501344

TahoeClim, Desert Research Institute. 2017 http://www.tahoeclim.dri.edu. Accessed 5 May 2017

Taylor, A.H. 2004. Identifying forest reference conditions on early cut-over lands, Lake Tahoe Basin, USA. Ecological Applications 14: 1903-1920. https://doi.org/ 10.1890/02-5257.

Thies, W.G., D.J. Westlind, and M. Loewen. 2005. Season of prescribed burn in ponderosa pine forests in eastern Oregon: Impact on pine mortality. International Journal of Wildland Fire 14: 223-231. https://doi.org/10.1071/ WF04051.

USDA Forest Service. 2012. increasing the Pace of Restoration and Job Creation on Our National Forests. Published Report. Washington, D.C: U.S. Department of Agriculture, Forest Service.

USDA Forest Service, California Dept. of Forestry \& Fire Protection, Bureau of Land Management, National Park Service, Bureau of Indian Affairs, U. S. Fish and Wildlife Service, Governor's Office of Emergency Services. 2016. California Mobilization Guide

USDA Forest Service Pacific Southwest Region. 2011. Region 5 Ecological Restoration, Leadership Intent. R5-MR-048, 4. Pacific Southwest Region: U.S. Department of Agriculture, Forest Service.

USDA Forest Service, Pacific Southwest Region. 2019. Spotlight: One Region, One Program of Work. https://www.fs.usda.gov/list/r5/home/list/?position= SubFeature. Accessed 29 Apr 2019

Vaillant, N.M., and E.D. Reinhardt. 2017. An Evaluation of the Forest Service Hazardous Fuels Treatment Program-Are We Treating Enough to Promote Resiliency or Reduce Hazard? Journal of Forestry 115 (4): 300-308 https://doi. org/10.5849/jof.16-067.

Vaillant, N.M., and S.L. Stephens. 2009. Fire history of a lower elevation Jeffrey Pine-mixed conifer forest in the eastern Sierra Nevada, California, USA. Fire Ecology 5: 4-19. https://doi.org/10.4996/fireecology.0503004.

van Wagtendonk, J., N. G Sugihara, S.L. Stephens, A.E. Thode, K.E. Shaffer, and J. Fites-Kaufman, editors. 2018. Fire in California Ecosystems. 2nd edition. University of California Press, Oakland.

Wang, S.-Y., L.E. Hipps, O. Chung, R.R. Gillies, and R. Martin. 2015. Long-term winter inversion properties in a mountain valley of the western United States and implications on air quality. Journal of Applied Meteorology and Climatology 54: 2339-2352. https://doi.org/10.1175/JAMC-D-15-0172.1.

Westerling, A.L., H.G. Hidalgo, D.R. Cayan, and T.W. Swetnam. 2006. Warming and earlier spring increase western U.S. forest wildfire activity. Science 313: 940943. https://doi.org/10.1126/science.1128834.

Western Regional Climate Center. 2017. SOUTH LAKE TAHOE AP, CALIFORNIA NCDC 1981-2010 Monthly Normals. Retrieved from https://wrcc.dri.edu/cgibin/cliMAIN.pl?ca8762

Yurkonis, K.A., J. Dillon, D.A. McGranahan, D. Toledo, and B.J. Goodwin. 2019 Seasonality of prescribed fire weather windows and predicted fire behavior in the northern Great Plains, USA. Fire Ecology 15: 7 https://doi.org/10.1186/ s42408-019-0027-y.

Zar, J.H. 1999. Biostatistical analysis. 4th ed, 663. Upper Saddle River: Prentice Hall.

\section{Publisher's Note}

Springer Nature remains neutral with regard to jurisdictional claims in published maps and institutional affiliations.

\section{Submit your manuscript to a SpringerOpen ${ }^{\circ}$ journal and benefit from:}

- Convenient online submission

- Rigorous peer review

- Open access: articles freely available online

- High visibility within the field

- Retaining the copyright to your article

Submit your next manuscript at $\boldsymbol{\nabla}$ springeropen.com 